\title{
Drying kinetics of Brazil nuts
}

\author{
Patrícia Cardoso SILVA ${ }^{1}$, Osvaldo RESENDE ${ }^{1}$, Weder Nunes FERREIRA JUNIOR ${ }^{1 \star ~(D), ~}$ \\ Lígia Campos de Moura SILVA ${ }^{1}$, Wellytton Darci QUEQUETO ${ }^{1}$, Fabio Adriano Santos e SILVA ${ }^{1}$
}

\begin{abstract}
The drying is one of the stages of processing Brazil nuts, being an important stage due to the high moisture content and water activity of the product. This study aimed to adjust mathematical models to the drying kinetics data of Brazil nuts, calculating the effective diffusion coefficient and obtaining activation energy for the drying process. Brazil nuts were collected in amazon region, and then the product was homogenized for processing. The nuts were subjected to drying in a forced ventilation oven at temperatures of $40,50,60,70$ and $80^{\circ} \mathrm{C}$ in 4 replicates, each one consisting of approximately $200 \mathrm{~g}$ of samples in aluminum containers. Mathematical models were adjusted to the experimental data of the moisture content ratio. Thompson, Midilli, Logarithmic and Two Terms models are suitable for estimating the drying of Brazil nuts. The Two Terms model was selected to represent the drying phenomenon for presenting better results in the analyzed parameters. The effective diffusion coefficient increased with increasing temperature and the activation energy for the liquid diffusion in the drying was $35.69 \mathrm{~kJ} \mathrm{~mol}^{-1}$.
\end{abstract}

Keywords: Bertholletia excelsa H. B. K.; Two Terms model; coefficient of diffusion.

Practical Application: Contribute to estimate the drying process of Brazil nuts in different conditions.

\section{Introduction}

Brazil nuts contain an almond of high nutritional value and bioactive composition, including unsaturated fatty acids, protein, fiber, micronutrients, vitamins, and phyto-chemicals, among them the selenium, phytosterols, tocopherol, squalene, and phenolic compouds all attributed to various potential health benefits (Yang, 2009; Gomes \& Torres, 2016). This product are consumed worldwide not only for their taste but also for their high protein (15\%), carbohydrate (9\%), lipid (71\%), and Se content (290.5 $\mu \mathrm{g}$ in $5 \mathrm{~g}$ on average) (Stockler-Pinto et al., 2014).

The commercialization of this product can be through the sale of the whole almond, the almonds inside the nuts, as well as the oil and the residue from the extraction (Brazil nut cake) (Stockler-Pinto et al., 2014; Picanço \& Costa, 2019). Brazil nuts are extracted from the interior of urchins (capsular woody fruit), 15-25 nuts per fruits (Bitencourt et al., 2020), during the period of collection of this product the climate is characterized by high relative humidity due to rain, condition positively influence the development of aflatoxin-producing microorganisms (Botelho et al., 2019). In addition, almonds are collected with a high moisture content and water activity and these characteristics contribute to the growth of aflatoxigenic fungi (Pacheco \& Scussel, 2007).

The drying is one of the stages of processing Brazil nuts, being an important stage due to the high moisture content and water activity of the product, so it is necessary to act efficiently to prevent the growth of fungi (Pacheco \& Scussel, 2007; Takeuchi \& Egea, 2020). According to Vilela \& Artur (2008), information obtained from drying curves is important for the development of equipment dimensioning processes. Thus, several mathematical models have been used to characterize the drying of plant products, representing well the loss of moisture along the drying process.

The rate of water removal from products during the drying is characterized by the diffusion coefficient (Goneli et al., 2007), and the relationship between the diffusion coefficient and the temperature can be described by the Equation of Arrhenius, which presents an activation energy for the liquid diffusion in the product. Goneli et al. (2017) report that water diffusion in plant products along drying involve several mechanisms, such as molecular diffusion, capillary diffusion, surface diffusion, among others, being a complex process.

Given the above, this study aimed to adjust mathematical models to the drying kinetics data of Brazil nuts (Bertholletia excelsa H. B. K.), calculating the effective diffusion coefficient and obtaining activation energy for the drying process.

\section{Materials and methods}

The experiment was carried out at the Laboratory of PostHarvest of Plant Products of the Instituto Federal de Educação, Ciência e Tecnologia Goiano - Campus of Rio Verde. Brazil nuts with initial moisture content of $19.02 \pm 0.235$ dry base $(\mathrm{db})$ were used.

Brazil nuts were collected in the municipality of Manaus$\mathrm{AM}$ and transported in their urchins to the LPCPV. The fruits denominated urchins were manually opened using metal knives to extract the nuts. Then, the samples were subjected to drying in a forced ventilation oven (Ethik technology 400-4ND) at 
temperatures of $40,50,60,70$ and $80^{\circ} \mathrm{C}$. The nuts were uniformly spread on rectangular aluminum trays $(25 \times 10 \mathrm{~cm})$ without perforations, each one containing $200 \mathrm{~g}$ of sample, with four replicates.

Drying was conducted until the nuts reached a constant mass. Mass reduction during drying was monitored using a semi-analytical balance with resolution of $0.01 \mathrm{~g}$ (SHIMADZU BL-3200H). Moisture content of nuts was determined by drying in the oven at $105{ }^{\circ} \mathrm{C}$ until constant weight, which required a time of $31.0 \mathrm{~h}$ (Brasil, 2009, adapted).

To the determine drying curves and adjustment the models was calculated the moisture content ratio of Brazil nuts along the drying process, the following Equation was used:

$$
R X=\frac{X-X_{e}}{X_{i}-X_{e}}
$$

Where, RX - Moisture content ratio of the product, dimensionless; $\mathrm{X}$ - Moisture content of the product (db); Xi - Initial moisture content of the product $(\mathrm{db})$; and $\mathrm{X}_{\mathrm{e}}$ - Equilibrium moisture content of the product (db).

Inside and outside the oven, drying air and ambient temperatures were monitored, while the relative humidity was obtained through basic principles of psychrometry, using the computer program GRAPSI, and was equal to $23.61 \%$ at the temperature of $40{ }^{\circ} \mathrm{C}$, to $14.12 \%$ at $50{ }^{\circ} \mathrm{C}$, to $7.15 \%$ at $60{ }^{\circ} \mathrm{C}$, $4.06 \%$ at $70{ }^{\circ} \mathrm{C}$ and to $3.03 \%$ at $80{ }^{\circ} \mathrm{C}$.

To determine the equilibrium moisture content of Brazil nuts, approximately $45 \mathrm{~g}$ of nuts were placed in capsules in three replications. The samples were placed in an oven at drying temperatures and were monitored at $24 \mathrm{~h}$ intervals until the product mass remained unchanged during three consecutive weighings. After the nuts were in equilibrium, the moisture content of the samples was determined in an oven at $105^{\circ} \mathrm{C}$ for $31 \mathrm{~h}$.

Mathematical models frequently used to represent the drying of plant products (Table 1) were fitted to the experimental data of Brazil nut drying (Equations 2 to 12).

The mathematical models were fitted using the GaussNewton method, through nonlinear regression. The degree of fit was determined based on the coefficient of determination $\left(\mathrm{R}^{2}\right)$, chi-square $\left(\chi^{2}\right)$, mean relative error $(\mathrm{P})$ and mean estimated error (SE). For the mean relative error, the value of $10 \%$ was considered as criterion to select the models according to Mohapatra \& Srinivasa Rao (2005).

Mean relative and estimated errors and chi-square value were calculated for each model using the following Equations 13, 14 and 15, respectively:

$\mathrm{P}=\frac{100}{\mathrm{~N}} \sum \frac{|\mathrm{Y}-\hat{\mathrm{Y}}|}{\mathrm{Y}}$

$\mathrm{SE}=\sqrt{\frac{\sum(\mathrm{Y}-\hat{\mathrm{Y}})^{2}}{\mathrm{DF}}}$

$\chi^{2}=\frac{\sum_{i=1}^{\mathrm{n}}(\mathrm{Y}-\hat{\mathrm{Y}})}{\mathrm{DF}}$

Where, Y - Experimental value; $\hat{Y}$ - Model-estimated value; $\mathrm{n}$ - Number of experimental observations; and DF - degree of

Table 1. Mathematical models used to predict the drying of plant products

\begin{tabular}{|c|c|c|}
\hline Model designation & Model & \\
\hline $\mathrm{RX}=1+\mathrm{a} \cdot \mathrm{t}+\mathrm{b} \cdot \mathrm{t}^{2}$ & Wang and Sing & $(2)$ \\
\hline$R X=a \cdot \exp (-k \cdot t)+(1-a) \cdot \exp \left(-k_{1} \cdot t\right)$ & Verma & (3) \\
\hline$R X=\exp \left(\left(-a-\left(a^{2}+4 \cdot b \cdot t\right)^{0.5}\right) / 2 \cdot b\right)$ & Thompson & $(4)$ \\
\hline $\mathrm{RX}=\exp -\mathrm{k} \cdot \mathrm{t}^{\mathrm{n}}$ & Page & $(5)$ \\
\hline $\mathrm{RX}=\exp (-\mathrm{k} \cdot \mathrm{t})$ & Newton & (6) \\
\hline$R X=a \cdot \exp \left(-k \cdot t^{n}\right)+b \cdot t$ & Midilli & (7) \\
\hline $\mathrm{RX}=\mathrm{a} \cdot \exp (-\mathrm{k} \cdot \mathrm{t})+\mathrm{c}$ & Logarithmic & $(8)$ \\
\hline $\mathrm{RX}=\mathrm{a} \cdot \exp (-\mathrm{k} \cdot \mathrm{t})$ & Henderson and Pabis & (9) \\
\hline $\mathrm{RX}=\mathrm{a} \cdot \exp (-\mathrm{k} \cdot \mathrm{t})+(1-\mathrm{a}) \exp (-\mathrm{k} \cdot \mathrm{a} \cdot \mathrm{t})$ & Two-Term Exponential & $(10)$ \\
\hline$R X=a \cdot \exp \left(-k_{0} \cdot t\right)+b \cdot \exp \left(-k_{1} \cdot t\right)$ & Two Terms & $(11)$ \\
\hline$R X=a \cdot \exp (-k \cdot t)+(1-a) \cdot \exp (-k \cdot b \cdot t)$ & Approximation of Diffusion & $(12)$ \\
\hline
\end{tabular}

Where, $\mathrm{t}$ - Drying time, $\mathrm{h} ; \mathrm{k}, \mathrm{k}_{\mathrm{o}}, \mathrm{k}_{1}$ - Drying constants, $\mathrm{h}^{-1}$; and a, b, c, n - Model parameters. 
freedom of the model (number of observations minus the number of parameters).

In order to select one single model to describe the drying process under each condition, those with best fits were subjected to Akaike (AIC) and Schwarz's Bayesian (BIC) information criteria.

The information criteria were determined by the Equations 16 and 17 :

$$
\mathrm{AIC}=-2 \log \mathrm{L}+2 \mathrm{p}
$$

$\mathrm{BIC}=-2 \log \mathrm{L}+\mathrm{p} \ln (\mathrm{N}-\mathrm{r})$

Where, L - Maximum likelihood; p - Number of model parameters; $\mathrm{N}$ - Total of observations; $\mathrm{r}$ - Rank of X matrix (incidence matrix for fixed effects).

The liquid diffusion model for the geometric form of an infinite cylinder, with approximation of eight terms (Afonso \& Corrêa, 1999), was fitted to the experimental data of Brazil nut drying, according to the following Equation 18:

$$
\mathrm{RX}=\frac{\mathrm{X}^{*}-\mathrm{X}_{\mathrm{e}}^{*}}{\mathrm{X}_{\mathrm{i}}^{*}-\mathrm{X}_{\mathrm{e}}^{*}}=\sum_{\mathrm{n}=1}^{\infty} \frac{4}{\lambda_{\mathrm{n}}^{2}} \exp \left[-\frac{\lambda_{\mathrm{n}}^{2} \cdot \mathrm{D} \cdot \mathrm{t}}{4} \cdot\left(\frac{2}{\mathrm{r}}\right)^{2}\right]
$$

Where, $\mathrm{n}$ - Number of terms; D - Liquid diffusion coefficient, $\mathrm{m}^{2} \mathrm{~s}^{-1} ; \mathrm{t}$ - Drying time, $\mathrm{h} ; \mathrm{r}$ - Equivalent radius, $\mathrm{m}$; and $\lambda_{\mathrm{n}}$ : - Roots of the zero-order Bessel equation.

The equivalent sphere radius was calculated by the following Equation 19:

$r=\sqrt[3]{\frac{3 \cdot V}{4 \cdot \pi}}$

The volume of each nut $\left(\mathrm{V} \mathrm{m}^{3}\right)$ was obtained by measuring the three orthogonal axes (length, width and thickness) of fifteen units, using a digital caliper with resolution of $0.01 \mathrm{~mm}$, according to the following Equation 20:

$\mathrm{V}=\frac{\pi \cdot \mathrm{A} \cdot \mathrm{B} \cdot \mathrm{C}}{6}$
Where, A - Length, m; B - Width, m; C - Thickness, m.

The relationship between diffusion coefficient and drying air temperature was analyzed by the Arrhenius equation, according to the following Equation 21:

$\mathrm{D}=\mathrm{D}_{0} \cdot \exp \left(\frac{-\mathrm{E}_{\mathrm{a}}}{\mathrm{R} \cdot \mathrm{T}_{\mathrm{abs}}}\right)$

Where, $\mathrm{D}_{0}$ - Pre-exponential factor; $\mathrm{E}_{\mathrm{a}}$ - Activation energy, $\mathrm{kJ} \mathrm{mol}^{-1}$; $\mathrm{R}$ - Universal gas constant $\left(8.134 \mathrm{~kJ} \mathrm{kmol}^{-1} \mathrm{~K}^{-1}\right) ; \mathrm{T}_{\mathrm{abs}}$ - Absolute temperature, $\mathrm{K}$.

Arrhenius Equation coefficients were linearized by applying a logarithm, as described below (Equation 22):

$\mathrm{LnD}=\mathrm{LnD}_{0}-\frac{\mathrm{E}_{\mathrm{a}}}{\mathrm{R}} \cdot \frac{1}{\mathrm{~T}_{\mathrm{abs}}}$

\section{Results and discussion}

Table 2 presents the values of chi-square $\left(\chi^{2}\right)$ and mean estimated error (SE) calculated for the eleven models used to represent the drying curve of Brazil nuts.

The mean estimated error (SE) describes the standard deviation of the estimate, showing wide variation between models and the respective temperatures. However, the adjustment of Thompson (4), Midilli (7), Logarithmic (8), Two terms (11) and Approximation of Diffusion (12) models had the lowest values of SE for most of the drying conditions. It should be emphasized that the lower the value of SE, the better the quality of a model's fit to the experimental data, the adjustment of Two Terms, which presented the lowest value of mean estimated error for all conditions.

In relation to the analysis of chi-square $\left(\chi^{2}\right)$, all model adjustments showed values for the test within the $5 \%$ confidence interval. The models Logarithmic (8), Two Terms (11) and Approximation of Diffusion (12) had lower values compared to the others, especially at the temperatures of 40,50 and $60^{\circ} \mathrm{C}$. The lower the values of chi-square, the better the fit of the model (Günhan et al., 2005).

Table 2. Values for chi-square $\left(\chi^{2}\right.$, decimal) and mean estimated error (SE, decimal) calculated for the models used to represent the drying

\begin{tabular}{|c|c|c|c|c|c|c|c|c|c|c|}
\hline \multirow{2}{*}{ Model } & \multicolumn{2}{|c|}{$40^{\circ} \mathrm{C}$} & \multicolumn{2}{|c|}{$50^{\circ} \mathrm{C}$} & \multicolumn{2}{|c|}{$60^{\circ} \mathrm{C}$} & \multicolumn{2}{|c|}{$70^{\circ} \mathrm{C}$} & \multicolumn{2}{|c|}{$80^{\circ} \mathrm{C}$} \\
\hline & $\mathrm{SE}$ & $\chi^{2}$ & SE & $x^{2}$ & $\mathrm{SE}$ & $x^{2}$ & $\mathrm{SE}$ & $x^{2}$ & $\mathrm{SE}$ & $x^{2}$ \\
\hline 2 & 0.057 & 33.33 & 0.085 & 72.28 & 0.096 & 93.76 & 0.108 & 117.34 & 0.033 & 11.34 \\
\hline 3 & 0.056 & 31.74 & 0.139 & 195.76 & 0.228 & 521.69 & 0.080 & 65.57 & 0.036 & 13.45 \\
\hline 4 & 0.024 & 5.87 & 0.031 & 9.64 & 0.026 & 7.20 & 0.026 & 6.93 & 0.033 & 11.44 \\
\hline 5 & 0.033 & 11.03 & 0.042 & 18.12 & 0.033 & 11.34 & 0.037 & 13.72 & 0.035 & 12.28 \\
\hline 6 & 0.051 & 26.67 & 0.074 & 55.40 & 0.064 & 41.33 & 0.076 & 58.28 & 0.033 & 11.38 \\
\hline 7 & 0.022 & 4.95 & 0.023 & 5.75 & 0.018 & 3.53 & 0.016 & 3.61 & 0.014 & 2.16 \\
\hline 8 & 0.021 & 4.69 & 0.020 & 4.09 & 0.015 & 2.26 & 0.015 & 2.53 & 0.023 & 5.46 \\
\hline 9 & 0.049 & 24.49 & 0.068 & 47.06 & 0.066 & 44.50 & 0.087 & 47.36 & 0.032 & 10.69 \\
\hline 10 & 0.030 & 9.34 & 0.050 & 25.35 & 0.049 & 24.44 & 0.053 & 28.59 & 0.033 & 11.27 \\
\hline 11 & 0.015 & 2.25 & 0.012 & 1.59 & 0.006 & 0.49 & 0.007 & 0.62 & 0.022 & 5.05 \\
\hline 12 & 0.020 & 4.18 & 0.018 & 3.28 & 0.010 & 1.04 & 0.080 & 65.57 & 0.036 & 13.45 \\
\hline
\end{tabular}
kinetics of Brazil nuts 
The coefficients of determination $\left(R^{2}\right)$ and mean relative error (P) are presented in Table 3. Madamba et al. (1996) state that the curves adjust must present $\mathrm{R}^{2}$ higher than $95 \%$. The adjustment of the models Thompson (4), Page (5), Midilli (7), Logarithmic (8), Two-Term Exponential (10) and Two Terms (11) have a coefficient of determination greater than $95 \%$.

The values of mean relative error $(\mathrm{P})$ were lower than $10 \%$, according to Mohapatra \& Srinivasa Rao (2005), indicate an adequate representation of the phenomenon, under all conditions tested for the models Thompson (4), Midilli (7), Logarithmic (8) and Two Terms (11), stood out as the most adequate to represent the drying phenomenon for the all conditions.

According to the parameters SE, $\chi^{2}, \mathrm{R}^{2}$ and $\mathrm{P}$, the models Two Terms, Midilli, Page, Logarithmic and Thompson were the most adequate to describe the drying of Brazil nuts. To complement the selection of the best model, Akaike (AIC) and Schwarz's Bayesian (BIC) information criteria were applied to the models Two Terms, Logarithmic and Midilli (Table 4). These parameters were used satisfactorily by Gomes et al. (2018) in the adjustment of models for the drying of crushed mass of jambu.

Akaike (AIC) and Schwarz's Bayesian (BIC) information criteria can confirm the superiority among the selected models (Thompson, Midilli, Logarithmic and Two Terms) because the lower the values of AIC and BIC, the better the fit of the model, according to Table 4 . Through a joint analysis of AIC and BIC, it was possible to observe that, among the models selected to represent the drying phenomenon, the Two Terms model fitted best to the experimental data because it showed the lowest values of AIC and BIC at all temperatures.

The Two terms model was recommended to estimate drying in solar dryers of cashew nuts and cowpea bean (Dhanushkodi et al., 2017; Alves et al., 2019). For the drying of the mortiño (Vaccinium meridionale Swartz) the Two terms model was also recommended to estimate the product's behavior in all study conditions (Lópes-Vidaña et al., 2017), as well as for drying 'Cabacinha' pepper seeds (Silva et al., 2018).

Table 5 presents the coefficients of the Two Terms model fitted to Brazil nuts drying data at different conditions of temperature and relative air humidity. The coefficients of the Two Terms model did not show linear behavior according to the drying temperature changes, corroborating with that observed by Quequeto et al. (2018) in the adjustment of the same model in the drying kinetics of noni seeds.

Regarding the coefficients of the Two Terms model (Table 5), it is observed that all the coefficients of this model in the different conditions were significant at $1 \%$ by the $t$ test, with the exception of the coefficients a and $\mathrm{k}_{0}$ for the temperature of $80^{\circ} \mathrm{C}$. There is no limitation in the literature that prevents the use of model adjustments with non-significant coefficients by the t-test. Parameters such as AIC and BIC consider the estimate

Table 3. Coefficient of determination $\left(\mathrm{R}^{2}, \%\right)$ along the drying of Brazil nuts at temperatures of $40,50,60,70$ and $80^{\circ} \mathrm{C}$

\begin{tabular}{|c|c|c|c|c|c|c|c|c|c|c|}
\hline \multirow{2}{*}{ Model } & \multicolumn{2}{|c|}{$40^{\circ} \mathrm{C}$} & \multicolumn{2}{|c|}{$50^{\circ} \mathrm{C}$} & \multicolumn{2}{|c|}{$60^{\circ} \mathrm{C}$} & \multicolumn{2}{|c|}{$70^{\circ} \mathrm{C}$} & \multicolumn{2}{|c|}{$80^{\circ} \mathrm{C}$} \\
\hline & $\mathrm{R}^{2}$ & $\mathrm{P}$ & $\mathrm{R}^{2}$ & $\mathrm{P}$ & $\mathrm{R}^{2}$ & $\mathrm{R}^{2}$ & $\mathrm{P}$ & $\mathrm{R}^{2}$ & $\mathrm{P}$ & $\mathrm{R}^{2}$ \\
\hline 2 & 96.55 & 14.37 & 87.20 & 22.86 & 90.08 & 96.55 & 14.37 & 87.20 & 22.86 & 90.08 \\
\hline 3 & 96.83 & 12.32 & 82.50 & 24.70 & 47.36 & 96.83 & 12.32 & 82.50 & 24.70 & 47.36 \\
\hline 4 & 99.39 & 4.76 & 98.98 & 7.36 & 99.23 & 99.39 & 4.76 & 98.98 & 7.36 & 99.23 \\
\hline 5 & 98.86 & 6.58 & 98.09 & 10.33 & 98.42 & 98.86 & 6.58 & 98.09 & 10.33 & 98.42 \\
\hline 6 & 97.15 & 14.04 & 93.97 & 23.62 & 94.04 & 97.15 & 14.04 & 93.97 & 23.62 & 94.04 \\
\hline 7 & 99.52 & 5.28 & 99.44 & 5.88 & 99.66 & 99.52 & 5.28 & 99.44 & 5.88 & 99.66 \\
\hline 8 & 99.53 & 5.95 & 99.58 & 5.88 & 99.77 & 99.53 & 5.95 & 99.58 & 5.88 & 99.77 \\
\hline 9 & 97.47 & 12.76 & 95.06 & 20.19 & 95.29 & 97.47 & 12.76 & 95.06 & 20.19 & 95.29 \\
\hline 10 & 99.25 & 7.48 & 97.34 & 16.35 & 97.41 & 99.25 & 7.48 & 97.34 & 16.35 & 97.41 \\
\hline 11 & 99.78 & 3.29 & 99.84 & 2.28 & 99.95 & 99.78 & 3.29 & 99.84 & 2.28 & 99.95 \\
\hline 12 & 99.58 & 4.23 & 99.66 & 3.30 & 99.89 & 99.58 & 4.23 & 99.66 & 3.30 & 99.89 \\
\hline
\end{tabular}

Table 4. Akaike (A) and Schwarz's Bayesian (B) selection criteria for the models Thompson (4), Midilli (7), Logarithmic (8) and Two Terms (11)

\begin{tabular}{|c|c|c|c|c|c|c|c|c|c|c|}
\hline \multirow{2}{*}{ Models } & \multicolumn{2}{|c|}{$40^{\circ} \mathrm{C}$} & \multicolumn{2}{|c|}{$50^{\circ}$} & \multicolumn{2}{|c|}{$60^{\circ} \mathrm{C}$} & \multicolumn{2}{|c|}{$70^{\circ} \mathrm{C}$} & \multicolumn{2}{|c|}{$80^{\circ} \mathrm{C}$} \\
\hline & AIC & BIC & AIC & BIC & AIC & BIC & AIC & BIC & AIC & $\mathrm{BIC}$ \\
\hline 4 & -143 & -139 & -115 & -111 & -58 & -54 & -80 & -78 & -51 & -49 \\
\hline 7 & -147 & -140 & -128 & -122 & -117 & -111 & -91 & -86 & -73 & -70 \\
\hline 8 & -150 & -144 & -139 & -134 & -129 & -124 & -99 & -95 & -61 & -58 \\
\hline 11 & -171 & -165 & -166 & -159 & -165 & -159 & -124 & -120 & -80 & -78 \\
\hline
\end{tabular}

Table 5. Coefficients of the Two Terms model for the drying of Brazil nuts at temperatures of 40, 50, 60, 70 and $80^{\circ} \mathrm{C}$

\begin{tabular}{cccccc}
\hline Coefficients & $40^{\circ} \mathrm{C}$ & $50^{\circ} \mathrm{C}$ & $60^{\circ} \mathrm{C}$ & $70{ }^{\circ} \mathrm{C}$ & $80^{\circ} \mathrm{C}$ \\
\hline $\mathrm{a}$ & $0.49788^{* *}$ & $0.67734^{* *}$ & $0.30919^{* *}$ & $0.31076^{* *}$ & $0.00947^{\text {ns }}$ \\
$\mathrm{k}_{0}$ & $0.05021^{* *}$ & $0.39032^{* *}$ & $0.05610^{* *}$ & $0.08349^{* *}$ & $-0.44738^{\text {ns }}$ \\
$\mathrm{b}$ & $0.54105^{* *}$ & $0.36077^{* *}$ & $0.71286^{* *}$ & $0.69761^{* *}$ & $1.03581^{* *}$ \\
$\mathrm{k}_{1}$ & $0.29317^{* *}$ & $0.04324^{* *}$ & $0.51527^{* *}$ & $0.79612^{* *}$ & $0.59619^{* *}$ \\
\hline
\end{tabular}

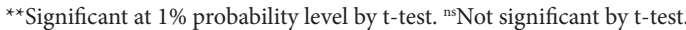


of these coefficients and the degree of adjustment, even though the estimate of these coefficients is not significant, it represented a good adjustment (Figure 1).

The Two Terms model at temperatures of 40, 50, 60, 70 and $80^{\circ} \mathrm{C}$ was used to graphically represent the drying curves (Figure 1). Based on the correspondence between experimental and estimated values, it was possible to note a good fit of the Two Terms model at all temperatures, to describe the drying of Brazil nuts.

It can be seen in Figure 1 that the increase in the drying temperature promotes a reduction in the time necessary for the product's water desorption to occur. The time required for drying to a moisture content ratio of $0.13 \pm 0.004$ was 23,20 ,

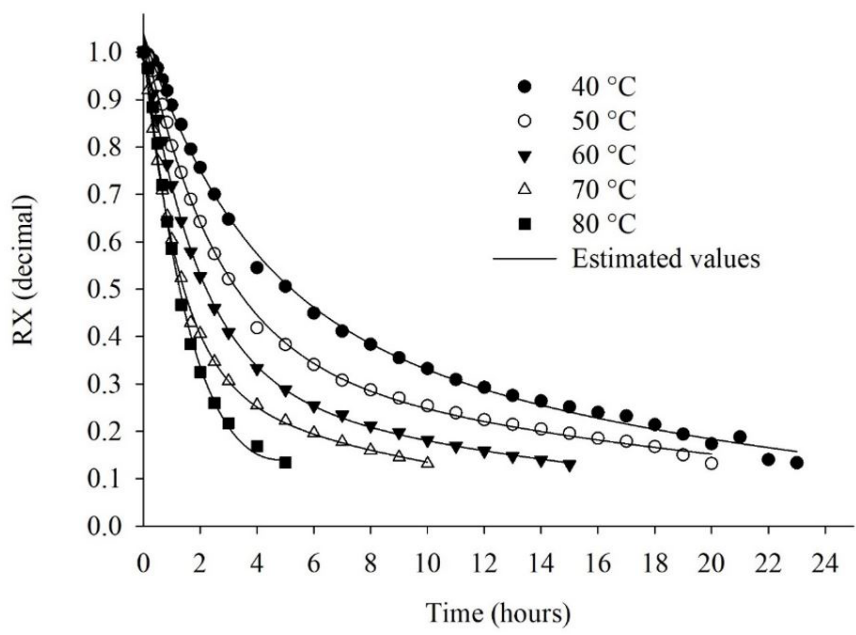

Figure 1. Moisture content ratio values of Brazil nuts estimated by the Two Terms model for the drying at temperatures of 40, 50, 60, 70 and $80^{\circ} \mathrm{C}$.
15,10 and 5 hours for temperatures of $40,50,60,70$ and $80^{\circ} \mathrm{C}$, respectively. The moisture content of nuts in this condition was $7.95 ; 6.77 ; 5.97 ; 4.19$ and $3.31 \%$ b.s. for temperatures of 40,50 , 60,70 and $80^{\circ} \mathrm{C}$, respectively.

According to Botelho et al. (2019) these moisture contents are safe for Brazil nuts storage since moisture contents below $8.2 \%$ b.s. are indicated by the authors for packaging temperatures below $55{ }^{\circ} \mathrm{C}$. The equilibrium moisture content of the nuts in the drying conditions was $0.89 ; 1.2 ; 3.25 ; 3.83$ and $5.31 \%$ b.s. for temperatures of $40,50,60,70$ and $80^{\circ} \mathrm{C}$, respectively, these values are used in Equation 1 to calculate the moisture content ratio.

Observed as the temperature increased, the effective diffusion coefficient increased linearly (Figure 2A), this relationship can be describe by the Arrhenius representation (Figure 2B).

The effective diffusion coefficients values were $0.66,0.94$, $1.43,2.27$ and $3.00 \mathrm{~m}^{2} \mathrm{~s}^{-1} \times 10^{-9}$ for the temperatures of 40,50 , 60,70 and $80{ }^{\circ} \mathrm{C}$, respectively. Madamba et al. (1996) report that the values of effective diffusivity coefficient in the drying of agricultural products have magnitudes from $10^{-9}$ to $10^{-11}$, note that the drying values of the nuts are within this range.

For baru fruits, Resende et al. (2018) obtained values from $1.20 \times 10^{-10}$ to $11.93 \times 10^{-10} \mathrm{~m}^{2} \mathrm{~s}^{-1}$ during the drying in the temperature range between $40{ }^{\circ} \mathrm{C}$ and $100{ }^{\circ} \mathrm{C}$. Thus, it can be inferred that water was removed faster in Brazil nuts, compared to baru fruits, because nuts are oilseeds and have higher hydrophobicity than fruits, which are carbohydrates.

The activation energy for the liquid diffusion in the drying of Brazil nuts, under the studied conditions of temperature (40, $50,60,70$ and $80{ }^{\circ} \mathrm{C}$ ), was $35.69 \mathrm{~kJ} \mathrm{~mol}^{-1}$. Souza et al. (2019) report the activation energy for liquid diffusion of sliced pulp
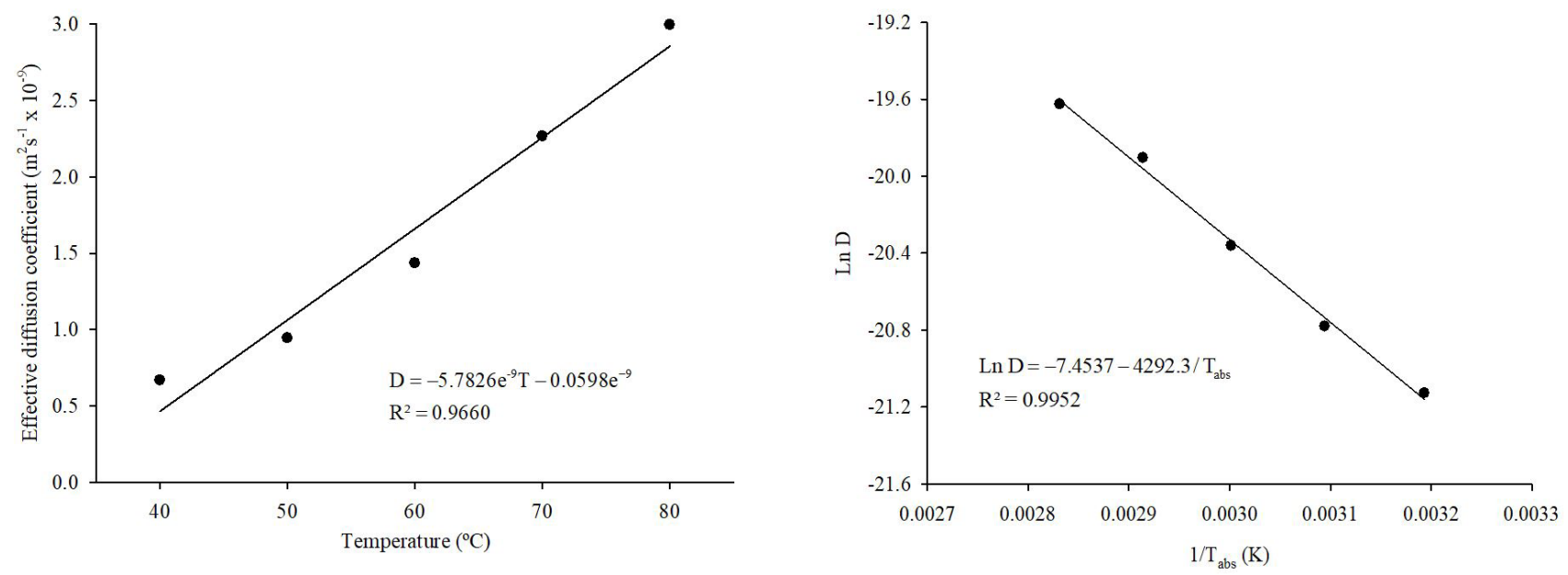

Figure 2. Effective diffusion coefficient representation for the effective diffusion coefficient, obtained for the drying of Brazil nuts at temperatures of $40,50,60,70$ and $80^{\circ} \mathrm{C}(\mathrm{A})$; Arrhenius representation for the effective diffusion coefficient, obtained for the drying of Brazil nuts at temperatures of $40,50,60,70$ and $80^{\circ} \mathrm{C}(\mathrm{B})$. 
of biofortified sweet potato was $29.18 \mathrm{~kJ} \mathrm{~mol}^{-1}$, the difference in the values of the variable is due to the physical and chemical differences between the products (Martins et al., 2015).

\section{Conclusions}

Among the models studied, the Two Terms model fitted better to the experimental data and was recommended to estimate the drying kinetics of Brazil nuts.

The effective diffusion coefficient increased with increasing temperature and the activation energy for the liquid diffusion on drying was $35.69 \mathrm{~kJ} \mathrm{~mol}^{-1}$.

\section{Acknowledgements}

To Instituto Federal de Educação, Ciência e Tecnologia Goiano, Coordenação de Aperfeiçoamento de Pessoa de Nível Superior, Fundação de Amparo à Pesquisa do Estado de Goiás, Financiadora de Estudos e Projetos and Conselho Nacional de Desenvolvimento Científico e Tecnológico for the indispensable financial support to conduct the study.

\section{References}

Afonso, P. C. Jr., \& Corrêa, P. C. (1999). Comparação de modelos matemáticos para descrição da cinética de secagem em camada fina de sementes de feijão. Revista Brasileira de Engenharia Agrícola e Ambiental, 3(3), 349-353. http://dx.doi.org/10.1590/1807-1929/ agriambi.v3n3p349-353.

Alves, R. A., Queiroz, A. J. M., Figueirêdo, R. M. F., Silva, W. P., \& Gomes, J. P. (2019). Solar drying of cowpea bean combined with drying in a heat accumulator dryer. Revista Brasileira de Engenharia Agrícola e Ambiental, 23(9), 709-775. http://dx.doi.org/10.1590/1807-1929/ agriambi.v23n9p709-715.

Bitencourt, M. A. F., Resende, O., Ferreira, W. N. Jr., Santos, M. R. B., \& Andrade, E. G. (2020). Pós-colheita, morfometria e rendimento de castanhas-do-Brasil da região amazônica. Alimentos: Ciência, Tecnologia e Meio Ambiente, 1(10), 13-38.

Botelho, F. M., Boschiroli, N. J. No., Botelho, S. C. C., Oliveira, G. H. H., \& Hauth, M. R. (2019). Sorption isotherms of Brazil nuts. Revista Brasileira de Engenharia Agrícola e Ambiental, 23(10), 776-781. http://dx.doi.org/10.1590/1807-1929/agriambi.v23n10p776-781.

Brasil, Ministério da Agricultura e Reforma Agrária - MAPA. (2009). Regras para análise de sementes. Brasília: MAPA.

Dhanushkodi, S., Wilson, V. H., \& Sudhakar, K. (2017). Mathematical modeling of drying behaviour of cashew in a solar biomass hybrid dryer. Resource-Efficient Technologies, 3(4), 359-364. http://dx.doi. org/10.1016/j.reffit.2016.12.002.

Gomes, P. F., Resende, O., Sousa, E. P., Oliveira, D. E. C., \& Araújo, F. R. No. (2018). Cinética de secagem da massa esmagada de 'jambu': difusividade efetiva e energia de ativação. Revista Brasileira de Engenharia Agrícola e Ambiental, 22(7), 499-505. http://dx.doi. org/10.1590/1807-1929/agriambi.v22n7p499-505.

Gomes, S., \& Torres, A. G. (2016). Optimized extraction of polyphenolic antioxidant compounds from Brazil nut (Bertholletia excelsa) cake and evaluation of the polyphenol profile by HPLC. Journal of the Science of Food and Agriculture, 96(8), 2805-2814. http://dx.doi. org/10.1002/jsfa.7448. PMid:26353901.

Goneli, A. L. D., Araujo, W. D., Hartmann, C. P. Fo., Martins, E. A. S., \& Oba, G. C. (2017). Drying kinetics of peanut kernels in thin layers.
Engenharia Agrícola, 37(5), 994-1003. http://dx.doi.org/10.1590/18094430-eng.agric.v37n5p994-1003/2017.

Goneli, A. L. D., Corrêa, P. C., Resende, O., \& Reis, S. A. No. (2007). Estudo da difusão de umidade em grãos de trigo durante a secagem. Food Science and Technology, 27(1), 135-140. http://dx.doi.org/10.1590/ S0101-20612007000100024.

Günhan, T., Demir, V., Hancioglu, E., \& Hepbasli, A. (2005). Mathematical modelling of drying of bay leaves. Energy Conversion and Management, 46(11-12), 1667-1679. http://dx.doi.org/10.1016/j.enconman.2004.10.001.

Lópes-Vidaña, E. C., Figueroa, I. P., Cortés, F. B., Rojano, B. A., \& Navarro Ocaña, A. (2017). Effect of temperature on antioxidant capacity during drying process of mortiño (Vaccinium meridionale Swartz). International Journal of Food Properties, 20(2), 294-305. http://dx.doi.org/10.1080/10942912.2016.1155601.

Madamba, P. S., Driscoll, R. H., \& Buckle, K. A. (1996). The Thin-layer drying characteristics of garlic slices. Journal of Food Engineering, 29(1), 75-97. http://dx.doi.org/10.1016/0260-8774(95)00062-3.

Martins, E. A. S., Lage, E. Z., Goneli, A. L. D., Hartmann, C. P. Fo., \& Lopes, J. G. (2015). Cinética de secagem de folhas de timbó (Serjania marginata Casar). Revista Brasileira de Engenharia Agrícola e Ambiental, 19(3), 238-244. http://dx.doi.org/10.1590/1807-1929/ agriambi.v19n3p238-244.

Mohapatra, D., \& Srinivasa Rao, P. (2005). A thin layer drying model of parboiled wheat. Journal of Food Engineering, 66(4), 513-518. http://dx.doi.org/10.1016/j.jfoodeng.2004.04.023.

Pacheco, A. M., \& Scussel, V. M. (2007). Selenium and aflatoxin levels in raw Brazil nuts from the amazon basin. Journal of Agricultural and Food Chemistry, 55(26), 11087-11092. http://dx.doi.org/10.1021/ jf072434k. PMid:18052094.

Picanço, C. A. S., \& Costa, R. S. (2019). Análise da cadeia produtiva da castanha-do-Brasil coletada na reserva biológica do Rio Trombetas, Oriximiná, Pará. Brazilian Journal of Development, 5(10), 1946019483. http://dx.doi.org/10.34117/bjdv5n10-170.

Quequeto, W. D., Resende, O., Silva, P. C., Silva, F. A. S., \& Silva, L. C. M. (2018). Drying kinetics of noni seeds. The Journal of Agricultural Science, 11(5), 250-258. http://dx.doi.org/10.5539/jas.v11n5p250.

Resende, O., Oliveira, D. E. C., Costa, L. M., \& Ferreira, W. N. Jr. (2018). Drying kinetics of baru fruits (Dipteryx alata Vogel). Engenharia Agrícola, 38(1), 103-109. http://dx.doi.org/10.1590/1809-4430-eng. agric.v38n1p103-109/2018.

Silva, H. W., Vale, L. S. R. Jr., Silva, C. F., Souza, R. C., \& Soares, R. S. (2018). Drying kinetics and physiological quality of 'Cabacinha' pepper seeds during storage. Revista Brasileira de Engenharia Agrícola e Ambiental, 22(4), 292-297. http://dx.doi.org/10.1590/1807-1929/ agriambi.v22n4p292-297.

Souza, D. G., Resende, O., Moura, L. C., Ferreira, W. N. Jr., \& Andrade, J. (2019). W. S. Drying kinetics of the sliced pulp of biofortified sweet potato (Ipomoea batatas L.). Engenharia Agrícola, 39(2), 176-181. http://dx.doi.org/10.1590/1809-4430-eng.agric.v39n2p176-181/2019.

Stockler-Pinto, M. B., Mafra, D., Moraes, C., Lobo, J., Boaventura, G. T., Farage, N. E., Silva, W. S., Cozzolino, S. F., \& Malm, O. (2014). Brazil nut (Bertholletia excelsa, H.B.K.) improves oxidative stress and inflammation biomarkers in hemodialysis patients. Biological Trace Element Research, 158(1), 105-112. http://dx.doi.org/10.1007/ s12011-014-9904-z. PMid:24504745.

Takeuchi, K. P., \& Egea, M. B. (2020). Bioactive compounds of the Brazil Nut (Bertholletia excelsa Bonpl.): nutritional and health aspects. In $\mathrm{H}$. N. Murthy \& V. A. Bapat (Eds.), Bioactive compounds in underutilized fruits and nuts (Chap. 13, pp. 207-221). Switzerland: Springer. http:// dx.doi.org/10.1007/978-3-030-30182-8_15. 
Vilela, C. A. A., \& Artur, P. O. (2008). Secagem do açafrão (Curcuma longa L.) em diferentes cortes geométricos. Food Science and Technology, 28(2), 387-394. http://dx.doi.org/10.1590/S0101-20612008000200018.
Yang, J. (2009). Brazil nuts and associated health benefits: a review. Lebensmittel-Wissenschaft + Technologie, 42(10), 1573-1580. http:// dx.doi.org/10.1016/j.lwt.2009.05.019. 